\title{
The effect of a modular art education programme on the personal-social development of preschool children
}

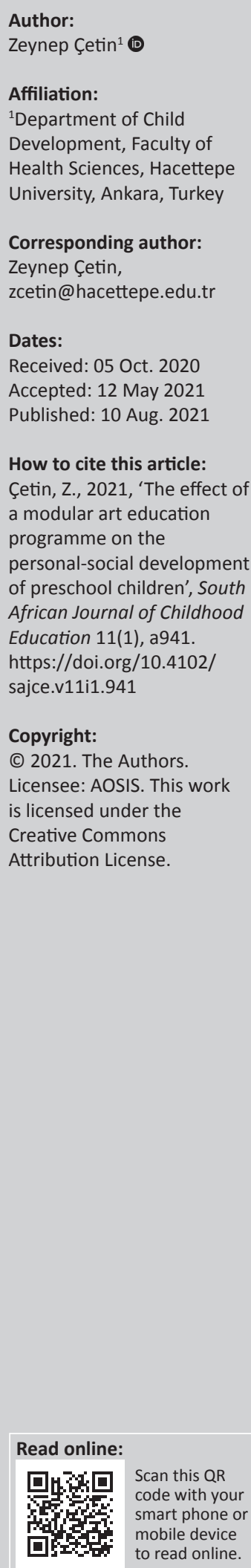

\begin{abstract}
Background: It is important for children to be engaged in art activities to acquire desirable emotions and behaviours. Art education is thought to contribute to children's development of personal and social skills, such as self-confidence and sharing.
\end{abstract}

Aim: This study aims to investigate the effect of art activities on 36-48-month-old children's personal and social development and offers suggestions for teachers and parents about art activities.

Setting and Methods: The sample included 56 children from the Duzce University Pre-School (28 children in the experimental group and 28 children in the control group). Quantitative data collection techniques were used, and randomised pre-test post-test experimental design with control groups was adopted. The experimental group received 7 weeks of art education developed by the researcher as six $45-50$ min sessions. The Brief Infant-Toddler Social and Emotional Assessment, which was adapted to Turkish was used as the data collection instrument. Variances were defined based on the data obtained. Content differences and frequency tables were formed and interpreted.

Results: Analysis of the data reveals a significant difference between the experimental and control groups' pre-test and post-test scores.

Keywords: early childhood; education; modular; art; programme; personal-social development.

\section{Introduction}

The preschool term is an important vital term in which children learn sharing, cooperation, socialising and learning to work together whilst preparing the primary education and to keep the acquired information continuing lifelong (Gultekin 2011; Sen 2006).

It is envisaged that the results of studies on art-based learning in this term will provide valuable contributions to the area of personal or social development closely related to emotions. Educating the children through art is one of the most important educational paths. It is seen that the most important reflection of the innovations in the 21st century education understanding is the art of understanding and methods used in child development and education. A basic element of art education is socialisation and communication, and these skills are also an expression of mental processes (Ayaydin 2011; Sen 2006; Ucan 1996).

Erikson transforms the psycho-sexual and social development of Freud (1979) into psycho-social development and ego development that encompasses all life. According to these theories, the elation of the individual is very supportive of his personal development (Gultekin 2011; Sagirkaya 2013).

Considering the fact that the foundations of personal and social development lie in the preschool ages, which are the early years of life, educational programmes should incorporate these developmental areas as early as possible. It is important to support the child's identity development in early childhood. Furthermore, in order to grow up children as being social, having selfconfidence, creative, se-expressive creative, self-expressive and fair individuals who listen to and understand others, art activities are crucial educational practices.

Early childhood years is a term when children make discoveries, play with interesting objects and use their creativity freely, and artistic emotions and intuitions emerge. In this period, children do not have schemas, prejudices and rules in their mind, so the creative process yields the most productive results. Art helps children bring together what they know about science, social studies, health, mathematics and literature (Brewer 2001; Dickie 2005; Wright 2003). 
Children need to develop their talent in artistic activities through drawings, pictures, sculptures, music, drama, dramatic play and dance. In this way, they have the chance to participate in situations related to other subjects or areas content to learn about more meaningful activities. The activities that are related to children's daily lives provide learning opportunities and help children to investigate the relationships between the objects they learn about (Goldhawk 1998; Vural 2009). In a similar vein, there are some important points regarding the effects of art therapy group activities and why they are recommended for children. First of all, some children need to express themselves through non-verbal modes of expression. Art can be viewed as an instrument of self-expression for children and adults who have difficulties with verbal expression. In addition, it has been argued that art is a holistic and experiential activity that enables the use of imagination (Bell 2012; Lifschitz-Grant 2012; Lucas 2014; Prokofiev 1998; Wong 2007).

In art education, children find an environment where they can play and create, build their own stories and animate their dreams. It is an educational tool that saves children from being passive. It contributes to children's use of imagination and communication skills and helps unleash disturbing emotions suppressed by the children. Art activities provide a natural environment that enables children to act freely. These activities also help to create an environment where children's specific characteristics can be observed, and ideas and symbolic thinking can develop by encountering various situations and events (Gultekin 2011). Thus, children's awareness about themselves and others increases, and they learn how to express themselves in a positive way. They also develop multidimensional thinking to evaluate events and relationships and learn about people as who they are through the art activities (Bozdogan 2003; Siverstone 1993). Moreover, Ulutas (2019) stated that preschool visual arts education can also contribute to social development.

In addition to reminding of the beauty of the divine, transcendent person in the artistic individual, he can manifest in spiritual pleasures such as serenity, peace and belonging in his spiritual world, in addition to the reflection, the beauty and the reflection of his behaviour in religious and social life (Aydeniz 2009; Furnham \& Chamorro-Premuzic 2004; Terr 2000). As well as Damasio (1999) and Freud (1979) are one of the most important aspects of education to know, develop and control the psychological orientations, psychological attitudes, personal characteristics and social situations of children and adult individuals. In this context, a good education is an indispensable element in the case where the theoreticians define it as a model learning, and the indispensable element emerges from the perspective of contributing to the socialisation; in this context, it will be appropriate to target the personal social development with art education.
The social skills that are required in preschool years enable individuals having good communication skills. Such skills also lead life-long success by contributing individuals' personal development. It is crucial to support the emergence of positive behaviours whilst taking into consideration early childhood needs. This study is based on the premise that children can acquire social skills by doing art activities.

\section{Methodology Research model}

This study used a randomised pre-test post-test design with control groups. In the single-group pre-test-post-test model, a randomly selected group in the argument is applied. Both pre-test and post-test measurements are made. It is assumed that the difference between the measurements obtained results from the application between pre-test and post-test (Neuman 2006).

\section{Participants}

The sample included 36-48-month-old girls and boys attending the Duzce University Pre-school in the city of Duzce. The children studied in three different classes, and their families had low socio-economic backgrounds. To control the teacher effect, same teachers applied the programme in three classes independent of each other. The experimental group consists of 28 children ( 13 boys and 15 girls) and the control group consists of 28 children also (14 boys and 14 girls). In the experimental group, 13 children were 36-41 months old, and 15 were $42-48$ months old. In the control group, 15 children were 36-41 months old, and the remaining 13 children were $42-48$ months old. The 36-41 months old children had been attending the preschool for a few months, whilst the 42-48 months old children had been attending the preschool for at least a year. Permission was obtained from the participants through a consent form.

\section{Data collection tools}

The data collection tools which used in this study were chosen by taking into account the variables to be measured and included the Personal Information Form that includes about demographic information the "The Brief InfantToddler Social and Emotional Assessment (BITSEA)-Turkish Version'.

\section{Child information form}

The Child Information Form, which asks participants about their gender, educational experience and age, was devised by the researchers.

\section{(K-1/3-SDD-TR) (19) The Brief Infant-Toddler Social and Emotional Assessment-Turkish version}

Another scale which was used in the current research was developed by several researchers (Briggs-Gowan et al. 2004) to determine 1-4-year-old children's levels of psychiatric 
symptoms and their psychosocial development (PD) problems. This questionnaire includes 42 questions, 31 of which were developed to assess children's psychiatric conditions (PC) and the remaining 11 were prepared to assess PD. Each item is scored on a three-point scale (0: not true/rarely; 1 : partially true/sometimes; and 2: highly true/ frequently). Higher PC values indicate higher levels of psychiatric problems, whereas higher PD scores indicate better PD. This study used only the 11-item psychosocial section of the instrument. The BITSEA has high internal consistency (0.79 BITSEA-P, 0.65 BITSEAC) and inter-rater reliability (0.68 BITSEA-P, 0.61 BITSEA-C) (Briggs-Gowan et al. 2004). The K1/3-SDD PS scores correlated significantly with the Child Behaviour Rating Scale, introversion $(p<0.001)$, extroversion $(p<0.0001)$ and total scores $(p<0.0001)$. The Turkish version of the scale's reliabilityvalidity analysis was performed by Karabekiroglu et al. (2009). The scale's test re-test reliability was found to be $0.85-0.87$.

\section{The modular art education programme}

The experimental group received a 7-week art education course developed by the researcher. After the educational

\begin{tabular}{|c|c|c|c|}
\hline Weeks & Kneading activity & Paper-collage activity & Painting activity \\
\hline Week 1 & Clay & Wrinkling-pasting & Water colour \\
\hline Week 2 & Salt ceramics & Cutting-pasting & Sugar paint \\
\hline Week 3 & Wax & Cut-paste & Spray technique \\
\hline Week 4 & Paste & Rounding-pasting & Ironing technique \\
\hline Week 5 & Paper dough & Cylindering-pleating & $\begin{array}{l}\text { Candle technique } \\
\text { dropping }\end{array}$ \\
\hline Week 6 & Wood dust dough & Honeycomb rounding & Blowing technique \\
\hline Week 7 & Modelling clay & Waste material matching & Press technique \\
\hline
\end{tabular}

programme was prepared, revisions were made on the basis of five experts' opinions, and then the art education was started. The programme was separated into three separate modules: painting, paper-collage and kneading. Each art education session lasted for $45-50 \mathrm{~min}$. Table 1 shows the content of the weekly art education modules. Children participated in the art activities without hardship, as envisaged in the programme (see Figure 1).

Sample waste materials: Crayons, dry paint, felt-tip pens, foam board, graphene cardboard, handwork seals, Turkish art paper (EVA), paper, clay, mud, ceramics, modelling clay, wax, paste, paper, paste and wood dust.

The activities included shaping the dough prepared by the researcher in the kneading activity, process-based product development in the paper-collage activity and technique-based painting in the painting activity.

Children were shown some slides related to the activity to ensure short instructions about the implementation of each technique before the activity process. After it was ensured that the children had learnt the technique, free art work activities were started. After the art education was completed, a post-test was administered.

\section{Analysis of data}

The data collected from the control and experimental groups were analysed using SPSS 15 . As the data were normally distributed, parametric tests, the independent samples $t$-test, the Kruskal-Wallis test and one-way analysis of variance were performed. Frequencies and percentages were also interpreted.
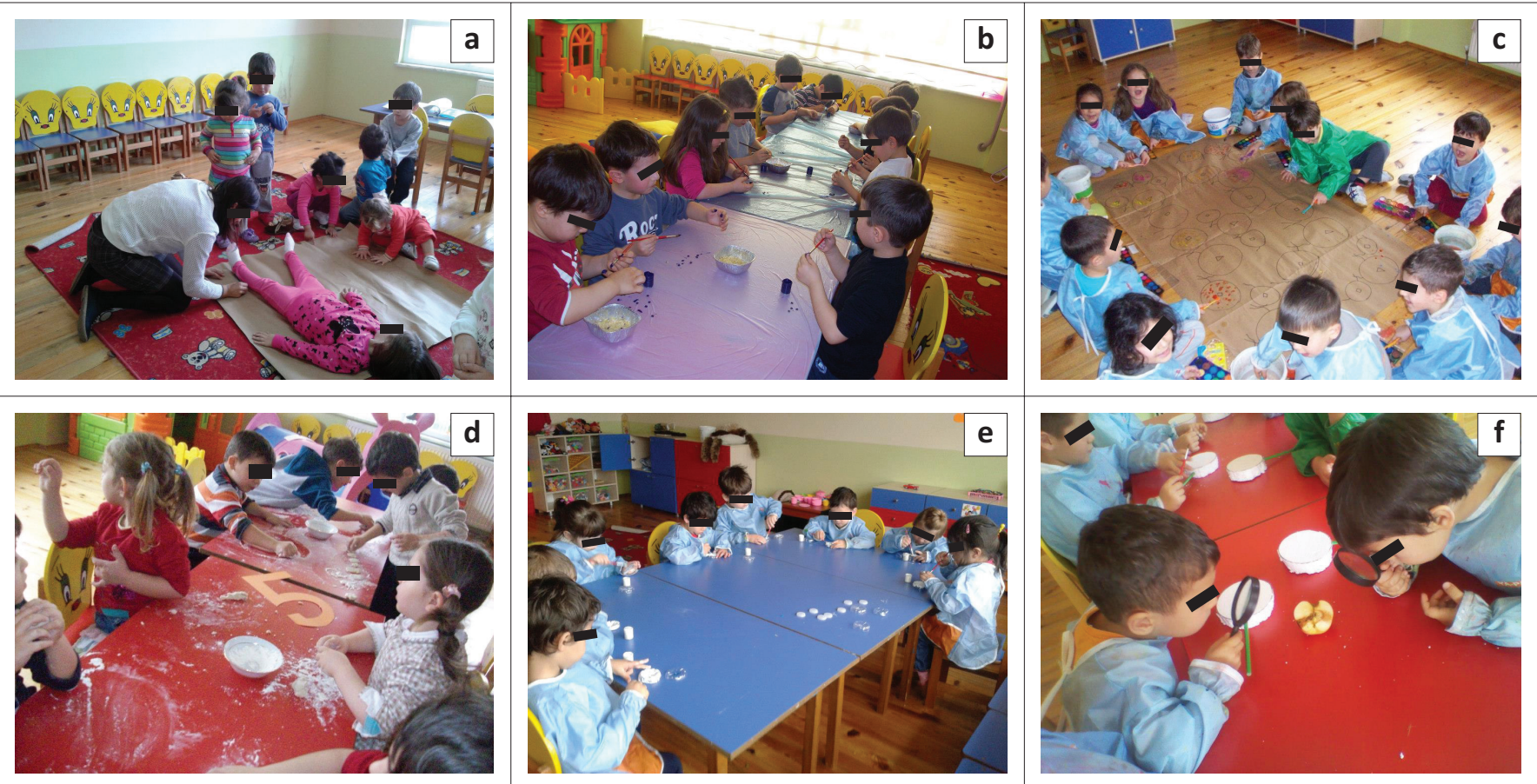

FIGURE 1: Some sections from the kneading and paper or collage works of the modular art education programme applied to children. 
TABLE 2: Mann-Whitney $U$ comparisons of the experimental and contro groups' Brief Infant-Toddler Social and Emotional Assessment pre-test and posttest scores.

\begin{tabular}{llccccc}
\hline Tests & Groups & $\boldsymbol{N}$ & $\boldsymbol{X}$ & $\begin{array}{c}\text { Sum of } \\
\text { ranks }\end{array}$ & $\boldsymbol{U}$ & $\boldsymbol{p}$ \\
\hline Pre-test & Experimental & 28 & 15.92 & 215.67 & 85.33 & 0.340 \\
& Control & 28 & 16.34 & 241.81 & & \\
Post-test & Experimental & 28 & 24.97 & 254.27 & 47.54 & $0.000^{*}$ \\
& Control & 28 & 18.67 & 216.97 & & \\
\hline
\end{tabular}

$X$, Average; $U$, Mann-Whitney $U$.

$*, p>0.05 ; p<0.05$.

TABLE 3: The $t$-test comparison of the experimental group's Brief Infant-Toddler Social and Emotional Assessment pre- and post-test scores.

\begin{tabular}{lccccc}
\hline Tests & $\boldsymbol{N}$ & $\boldsymbol{X}$ & $\mathrm{SD}$ & $\boldsymbol{t}$ & $\boldsymbol{p}$ \\
\hline Pre-test & 28 & 15.92 & 10.025 & & \\
Post-test & 28 & 24.97 & 5.321 & 0.470 & 0.002 \\
\hline
\end{tabular}

$X$, Average; SD, Standard deviation.

$p<0.05$.

\section{Findings}

This section presents tables and interpretations related to the findings of this study.

Table 2 shows the experimental and control groups' pre- and post-test scores. There was no significant difference between the experimental and control groups' BITSEA pre-test scores; however, the two groups' BITSEA post-test scores differed significantly.

Table 3 shows the information about the 36-48-month-old experimental group's personal and social development data. This group's BITSEA pre- and post-test scores were examined. According to the results, there is a statistically significant difference between the participants' pre-test and post-test scores. In fact, their post-test scores were significantly higher than pre-test scores.

Table 4 shows that there is no significant difference in BITSEA pre- and post-test scores of the boys and girls in the experimental group $(p>0.05)$. The change in their BITSEA scores after the modular art education programme varied by gender.

Table 5 shows the experimental group's pre- and post-test scores by age. The results show that there was a significant difference between 36-41-month-old children and 42-48-month-old children's pre-test and post-test mean scores, with data in favour of the latter group. A closer look at the data reveals an increase in personal and social score means for both age groups after the art education.

\section{Discussion, conclusion and suggestions}

It is crucial to support the social skills acquired in the preschool period with well-designed educational programmes. This study was based on the premise that modular art education affects children's socio-emotional development.
TABLE 4: The experimental group's Brief Infant-Toddler Social and Emotional Assessment pre- and post-test scores by gender.

\begin{tabular}{lllcccc}
\hline Tests & Sex & $\boldsymbol{N}$ & $\boldsymbol{X}$ & SD & $\boldsymbol{t}$ & $\boldsymbol{p}$ \\
\hline Pre-test & Male & 13 & 14.23 & 9.123 & 0.450 & 0.302 \\
& Female & 15 & 16.01 & 8.827 & & \\
\multirow{2}{*}{ Post-test } & Male & 13 & 26.58 & 6.105 & 0.063 & 0.154 \\
& Female & 15 & 23.54 & 6.316 & & \\
\hline
\end{tabular}

$X$, Average; SD, Standard deviation.

$p>0.05$.

TABLE 5: The experimental group's Brief Infant-Toddler Social and Emotional Assessment pre- and post-test scores by age.

\begin{tabular}{lcccccc}
\hline Tests & Age range (month) & $\boldsymbol{N}$ & $\boldsymbol{X}$ & SD & $\boldsymbol{t}$ & $\boldsymbol{p}$ \\
\hline Pre-test & $36-41$ & 13 & 09.84 & 9.123 & 1.458 & $0.006^{*}$ \\
& $42-48$ & 15 & 17.78 & 8.827 & & \\
Post-test & $36-41$ & 13 & 20.82 & 10.401 & 3.318 & $0.001^{*}$ \\
& $42-48$ & 15 & 27.74 & 11.713 & & \\
\hline
\end{tabular}

$X$, Average; SD, Standard deviation.

$*, p<0.05$.

The study shows that the modular education programme was administered to the experimental group, and a significant positive change was observed in personal and social competencies of children in each group.

The experimental group's pre- and post-test scores indicate the performance of art education programme. In the control group, there was no significant difference between the preand post-test scores of children. The slight increase in the control group's scores may be related to the fast development of the children considering their age.

Although there is a dearth of research on the relationship between artistic activities and social skills, it is thought that aesthetic sensitivity, creativity and art prevent the deterioration of societies' social skills and regression (Sahin 2006; Tasdelen \& Yazici 2012). According to Ture (2007), artistic learning is the creative activity process between the individual and the work (product model). Artistic learning occurs through planned, meaningful relationships created in pre-programmed aesthetic activities between the teacher and the learner. Children can only recognise and use objects in a social environment, which is the most significant factor creating a ground for their artistic development. In this respect, art education can significantly contribute to children's social development.

Based on extensive research, Artut (2004) argued that children's personal and social needs are closely related to the recognition of some artistic symbols, and the marks emerging in the child's world through drawing and painting, unclear lines and figures are signs of children's communication and social recognition. Bolat-Aydogan (2020) stated that even children's art books can contribute to social development.

Yavuzer (1999) argued that children's failure in artistic activities should be evaluated as a developmental problem rather than a skills-related problem. A child who cannot proceed to a higher level in artistic work probably cannot reach the psycho-social maturity for their age and will not 
be able to accomplish some activities performed by their peers.

Otgun (2009) and Armstrong (1994) found six areas of development that are influenced by artistic activities and works: emotional, physical, perceptual, social, aesthetic and creative. They pointed to personal preferences and social interaction to emphasise the effect of artistic activities on personal and social development. In addition, they highlighted the distinction between children's art and adult art, as well as the importance of art in young children's education as a unifying social activity.

Mynaříková (2012) administered art education to 11- and 12-year-old children and recorded positive effects on the children's social and emotional development.

Studies of children's drawings have found that children's social, personal and psycho-social condition is indirectly reflected in their paintings (Artut 2002; Gultekin 2011; Gultekin \& Yildiz 2009).

Considering children's works as an artistic activity, art education can be associated with children's personal and social development. In addition, research indicates that aesthetics and creativity, which are key components of art education, correlate with children's social development (Barnes-Smith et al. 2015; Getzels \& Jakson 1962).

The researches related the study shown that there was no significant difference between the experimental group's preand post-test BITSEA scores by gender. However, some art education studies reported gender-related changes (Altinkopru 2003; Ari \& Secer 2004; Can 2003; Persad \& Soafer 2016).

In the study, the experimental group's social development was assessed as BITSEA pre- and post-test scores, and the 42-48-month-old children were found to have significantly higher scores than the 36-41-month-old children. It can be argued that as their age increases, children's socioemotional skills improve as well. In many artistic activities, for example, in children's drawings, age-related stages have been proposed, which supports this study's agerelated findings. An analysis of the literature reveals that children's artistic activities significantly change depending on age (Cherney et al. 2006; Freilich \& Shechtman 2010; Guven 2015; Oguz 2010). Researchers have studied children's artistic development and free drawings and defined five developmental stages by age. The stages are (Ahi, Cingi \& Kildan 2016; Bayram et al. 1999; Collado 1999) as follows:

1. Scribble period: It is observed between the ages of 2 and 4 years.

2. Pre-schema period: It is observed between the ages of 4 and 7 years.

3. Schematic period: It is observed between the ages of 7 and 9 years (starting period of primary school).
4. Realism period: It is observed between the ages of 9 and 12 years.

5. Visible naturalism period: It is observed between the ages of 12 and 14 years.

Similarly, Freud (1979) and Bandura (1976) also stated that artistic studies may be more effective than logical mathematical activities on self-confidence and socialisation. Robertson (1999) reported that art education contributed to socialisation more effectively than social media and electronic networks, and that it contributed to real socialisation rather than virtual socialisation, both of which were made at the desk.

Studies of artistic works in early childhood reveal that active group work, especially in fine art, contributes to children's social and personal development and improves cooperation and collaboration skills (Lyon et al. 2016; Uysal 2005; Yolcu 2004). Contributions to socialisation include work discipline, cooperation with others, being influenced, criticism, participation in activities, developing group harmony, sharing and cleaning up the workplace. Contributions to personality development include eliminating fights and anger, eliminating hate and angry emotions by clay kneading, developing attention, improving observation skills, patience, self-confidence, independent thinking and acting freely and without pressure (Dizdar-Terwiel 2010; Erbay 1997; Gencaydin 1993; Kouvou 2016; Unver 2016).

Torrance (2002) argues that music, drawing and art influence the development of children's social life and creativity, especially at early ages. For this reason, in early childhood period artistic activities are recommended for children's personal and social development.

Moreover, Yukay-Yuksel (2020) stated that arts education programmes are closely related to social development and similar cultural elements.

In the experimental group, stereotypical habits were observed, especially in the paper or collage works. In the painting and kneading works, the children acted more freely. This indicated that memorised knowledge is more dominant in paper collage works.

The findings indicated that the social development of the experimental group significantly differed from that of the control group after the art education. There was a significant difference in the experimental group's pre- and post-test scores, whilst there was no significant difference in the control group's pre- and post-test scores. Thus, it can be argued that one way to support children's social development is to use artistic activities.

Depending on developmental and perception levels, it is critical that the programmes are centred on the senses, psycho-motor skills, aesthetics and comprehension. In this 
way the artistic activities focus on production rather than on their products and the process is emphasised.

The findings of this study suggest that use of the same shapes and templates should be avoided to prevent stereotypical art production, and that children should be encouraged to use different techniques in their works.

Teachers should be reminded that artistic activities should be process-oriented rather than product-oriented, which is more important for children's personal and social development. In a paper collage activity, the children's products should not be evaluated in terms of dimension, level, template or proportional metrics. The focus should be on their contribution to children's social development and nature.

Artistic activities should be carried out in small groups. In the activities, children should be free; however, the activities should not be disorganised in terms of content. The activities should be organised in graded and regular modules.

Parents should be instructed that artistic activities are a component of children's development, and therefore it is essential that children should be provided with rich opportunities and be free to play. Carrying out artistic activities with children's peers would be more beneficial.

For researchers, it can be recommended that sub-branches of artistic activities should be evaluated in terms of children's personal and social development. Children's artistic activities can also be compared with other technological activities, and the effects of these activities on children's personal and social development can be compared. In future studies, a survey design can be used with larger samples.

\section{Acknowledgements Competing interests}

The author has declared that no competing interest exists.

\section{Author's contributions}

I declare that I am the sole author of this research article.

\section{Ethical considerations}

This article followed all ethical standards for a research without direct contact with human or animal subjects.

\section{Funding information}

This research received no specific grant from any funding agency in the public, commercial or not-for-profit sectors.

\section{Data availability}

Data sharing is not applicable to this article as no new data were created or analysed in this study.

\section{Disclaimer}

The views and opinions expressed in this article are those of the authors and do not necessarily reflect the official policy or position of any affiliated agency of the authors.

\section{References}

Ahi, B., Cingi, M. \& Kildan, A., 2016, 'Examining 48-60 months old children's perceptions about teacher concept by analyzing their drawing', Elementary Education Online 15(1), 77-90. https://doi.org/10.17051/io.2016.97994

Altinkopru, T., 2003, Personality analysis, Hayat Publishing, Istanbul.

Ari, R. \& Secer, Z., 2004, 'Examining the skills of recognizing emotional facial expressions in terms of various variables of preschool children', The Journal of Selcuk University Social Sciences Institute 11, 67-84.

Armstrong, C., 1994, Designing assessment in art, NAEA (National Art Education Association), Reston, VA.

Artut, K., 2002, Theory of art education and methods, Ani Publishing, Ankara.

Artut, K., 2004, Theory of art education and methods, Ani Publishing, Ankara.

Ayaydin, A., 2011, 'Art and painting as a game in child development', Electronic Journal of Social Sciences 10(37), 303-316.

Aydeniz, H., 2009, 'The relationship between religion-art and this physical reflection of Mevlevi Sema ritual', Ataturk University Faculty Theology Journal 32, 35-51.

Bandura, A., 1976, The role of modeling processes in personality development, pp. 42-58, National Association for the Education of Young Children, Washington.

Barnes-Smith, D.L., Frotz, J., Ito, H., Kohorst, J. \& Vascimini, H., 2015, 'Expressive arts as a means of increasing well-being in children', Undergraduate theses and professional papers, University of Montana ScholarWorks, Missoula, MT.

Bayram, E., Ozgul, E., Kaplan, G., Unal, A., Yapagili, H., Demir, K. et al., 1999, Creativity at primary school, I.M.E.B (Ministry of National, Education in Turkey) State Books, Ankara.

Bell, D., 2012, 'Talking about art with young people: Conversational strategies for aesthetic learning in early childhood settings', International Art in Early Childhood 3(1), 1-17.

Bolat-Aydogan, K.E., 2020, 'Children's art books as an educational tool in art education', Anadolu Journal of Educational Sciences International 10(1), 763-789. https://doi.org/10.18039/ajesi.682145

Bozdogan, Z., 2003, Okulda rehberlik etkinlikleri ve yaraticı drama, Nobel Yayın Dağıtım, Ankara.

Brewer, J.A., 2001, Introduction to early childhood education, Allyn and Bacon, Boston.

Briggs-Gowan, M.J., Carter, A.S., Irwin, J.R., Wachtel, K. \& Cicchetti, D.V., 2004, 'The brief infant-toddler social and emotional assessment: Screening for socialemotional problems and delays in competence', Journal of Pediatric Psychology 29(2), 143-155. https://doi.org/10.1093/jpepsy/jsh017

Can, G., 2003, Gelişim ve öğrenme psikolojisi, 5. baskı., Pegem A Yayınları, Ankara

Cherney, I.D., Seiwert, C.S., Diceky, T.M. \& Flichtbeil, J.D., 2006, 'Childrens' drawings: A mirror to their minds', Educational Psychology 26(1), 127-142. https://doi. org/10.1080/01443410500344167

Collado, F.Y., 1999, 'The role of spontaneous drawing in the development of children in the early childhood settings', in U.S. Department of Education National Resources Information Center (ERIC), pp. 3-15, Reports Descriptive no. 141.

Damasio, A.R., 1999, Descartes'in Yanılgısı (Duygu-akıl ve insan beyni), Varlık Yayınları, Çev. Bahar Atlamaz, İstanbul.

Dickie, G., 2005, 'Aesthetics and the philosophy of art, the analytic tradition, an anthology', in P. Lamarque \& S. H. Olsen (editörler), The new institutional theory of art, pp. 4-18, Blackwell Publishing, Oxford.

Dizdar-Terwiel, C., 2010, Okulöncesi sanat eğitiminde bir malzeme olarak 'Kil' in yeri, p. 258, Ankara Üniversitesi Rektörlüğü Yayınları.

Erbay, M., 1997, Development of plastic arts education, Bogazici University Publishing, Istanbul.

Freilich, R. \& Shechtman, Z., 2010, 'The contribution of art therapy to the social, emotional, and academic adjustment of children with learning disabilities', The Arts in Psychotherapy 37(1), 8-12. https://doi.org/10.1016/j.aip.2010.02.003

Freud, S., 1979, On art and artists, transl. K. Sipal, Bozok Publishing, Istanbul.

Furnham, A. \& Chamorro-Premuzic, T., 2004, 'Personality, intelligence and art', Personality and Individual Differences 36(3), 705-715. https://doi.org/10.1016/ S0191-8869(03)00128-4

Gencaydin, Z., 1993, Education of art, Open Education Faculty Publications, Eskisehir.

Getzels, J.W. \& Jackson, P.J., 1962, Creativity and intelligence: Explorations with gifted students, John Wiley and Sons, Inc., New York, NY.

Goldhawk, S., 1998, Children and the arts: Making creative connections, Arts Education Partnership Council of Chief State School Officers, Washington, DC.

Gultekin, B. \& Yildiz, E., 2009, Child figures on communication, Nobel Publishing, Ankara.

Gultekin, T., 2011, 'Child and communication in the process of development of aesthetic values in art education', E-Journal of International Refereed Social Sciences 24, 1-14. 
Guven, G., 2015, 'Investigation of children's paintings of 4-5 year old children according to age, gender and socioeconomic status variables', Education Sciences 10(3), 204-211. https://doi.org/10.12739/NWSA.2015.10.3.1C0642

Karabekiroglu, K.A., Rodopman-Arman, P., Ay, M., Ozkesen, S., Akbas, G.N., Tasdemir O. et al., 2009 "The reliability and validity of the Turkish version of the brief infant and toddler social and emotional assessment (BITSEA)' Infant Behaviour Development 32(3), 291-297. https://doi.org/10.1016/j.infbeh.2009.03.003

Kouvou, O., 2016, 'Drawing with children: An experiment in assisted creativity', The International Journal of Art \& Design Education 35(2), 275-290. https://doi. org/10.1111/jade.12056

Lifschitz-Grant, N.L., 2012, 'Art education as a process of collaborative learning among children, parent and teachers in an early childhood classroom', Unpublished doctoral thesis, Columbia University.

Lucas, C., 2014, 'An early childhood creative arts program in the state of California: A parallel study using four preschools', Unpublished doctoral thesis, Jones International University.

Lyon, P., Letschka, P., Ainsworth, T. \& Haq, I., 2016, 'Drawing pedagogies in higher education: The learning impact of a collaborative cross-disciplinary drawing course', The International Journal of Art \& Design Education 37(2), 221-232. https://doi.org/10.1111/jade.12106

Mynaříková, L., 2012, 'Art-based program for social and emotional development of children', US-China Education Review A 8, 720-726.

Neuman, W.L., 2006, Social research method: Qualitative and quantitative approaches, Pearson Education, Bacon.

Oguz, V., 2010, 'The factors influencing childrens' drawings', Procedia-Social and Behavior Sciences 2(2), 3003-3007. https://doi.org/10.1016/j.sbspro.2010.03.455

Otgun, C., 2009, 'Approach types of art production', Journal Of Gazi Art Design 2, 159-178.

Persad, R. \& Sofaer, J., 2016, 'Creativity in the bronze age: Bringing archaeological research into contemporary craft teaching and learning through a live project authors', The International Journal of Art \& Design Education 37(2), 277-286. https://doi.org/10.1111/jade.12114

Prokofiev, F., 1998, 'Adapting the art therapy group for children', in S. Skaife \& V. Huet (eds.), Art psychotherapy groups: Between pictures and words, pp. 15-26, Brunner Routledge, Hove.

Robertson, A., 1999, Globalization, Science and Art Publishing, Ankara.

Sagirkaya, P., 2013, 'The effect of painting education on emotional (psycho-social) intelligence development of children between the ages of 7 and 11', Master's thesis, Cumhuriyet University, Education Sciences Institute, Sivas.
Sahin, M., 2006, 'Analysis of pictures of secondary school students with low socioeconomic level according to personality traits', Master's thesis, Gazi University Education Sciences Institute, Ankara.

Sen, Y., 2006, 'The importance of music on childrens' development in preschool term', Journal of Ataturk University Social Sciences Institute 7(1), 337-343.

Siverstone, L., 1993, Art therapy the person centred way: Art and the development of the person, Autonomy Books, London.

Tasdelen, D. \& Yazici, A., 2012, Philosophy of aesthetic and art, 1st edn., Anadolu University, Faculty of Open Learning, Eskisehir.

Terr, L., 2000, Beyond love and work is the game a need for adults?, transl. M. Koseoglu, Literature Publishing, Istanbul.

Torrance, E.P., 2002, The manifesto: A guide to developing a creative career, Ablex Publishing Corporation, New York.

Ture, N., 2007, 'Contribution of the visual arts course as a tool in education and education to the students', Unpublished Master's thesis, Selcuk University Social Sciences Institute, Konya.

Ucan, A., 1996, Human and music - Human and education of art, Music Encyclopedias Publishing, Alf, Ankara.

Ulutas, I., 2019, Visual art education in preschool, Hedef Publishing, Ankara.

Unver, E., 2016, 'The art education about why and how?', Idil 5(23), 865-878. https:// doi.org/10.7816/idil-05-23-05

Uysal, A., 2005, 'The effect of art education on creativity which given on secondary education', The Journal of Gazi University Kirsehir Education Faculty 6(1), 41-47.

Vural, D.U., 2009, Artistic (graphical) development steps of the child, art education and visual arts teaching, in A. Alakuş \& L. Mercin (eds.), pp. 21-35, Pegem A Publishing, Ankara.

Wong, K.M.B., 2007, 'Conceptions of art in Hong Kong preschool children', Australian Journal of Early Childhood 32(4), 31-36. https://doi.org/10.1177/ 183693910703200407

Wright, S., 2003, The arts, young children, and learning, Pearson, Boston, MA.

Yavuzer, H., 1999, Childa psychology, Remzi Bookshop, Istanbul.

Yolcu, A., 2004, 'Values of visual arts education in pre-school period', Journal of Erzincan Education Faculty 12(1), 187-200.

Yukay-Yuksel, M., 2020, 'Training program for gaining cultural elements with drama and art activities: My culture, my identity', Journal of Education Sciences 52(52) 505-528. https://doi.org/10.15285/maruaebd.619600 